procedure relationship, the law enforcement should be regulated by the provisions of the law. That explains the long work on the new Code of Criminal Procedure of Ukraine. The scientists try to establish and propose the provisions which could consider the rights and freedoms of not only victim but also suspected in a crime. Bearing in mind the nature of modern criminality and the personal qualities of criminals the legislation significantly expands the cognitive activity means. The Code of Criminal Procedure is completed by the chapter 21 whose the provisions define the mode to make the covert investigative (search) activities.

The investigative actions are one of the well-established institute of the criminal procedure. They are a part of the procedure actions that have the search, cognitive approach and provide the law of evidence. Their definition is the actions provided by criminal procedure law whose the approach is to obtain and check the getting evidences in the criminal procedure. They are provided by the investigator or the person conducting inquiry (in the cases provided by law - by the prosecutor and the chief of the investigators service) on the stage of pre-trial investigation according to the procedure requirements that have the cognitive approach.

The establishment of the covert investigative (search) activity institute is the natural result of the criminal procedure law development whose the goal is to guarantee the rights and the interests of two parts of criminal procedure. The search of the modern ways of getting information necessary to solve a crime and to bring perpetrators to justice and to restore the rights of victims will continue in the future. The scientists' proposals concerning the improvement of the getting information means for the criminal procedure are aimed to balance the opportunities of parts to achieve the true objective that the article 31 of Ukrainian law says. The investigator must have the effective cognitive activity means to provide the reliable information support for the adversarial proceedings. He can't be in worse conditions than the defense in the laws of evidence. If the defense can use any means to get the information source but not the criminal means, the investigator can use only the means provided by law (to respect the procedural law).

Key words: crime, means of cognitive activity, investigative (search) activities, proceedings, search, retrieval, investigative actions.

Маличева Н.P. доктор юридичних наук, професор, академік НАПрН України, завідувач відділу проблем аграрного, земельного, екологічного та космічного права Інституту держави і права імені В. М. Корецького НАН України (м. Київ, Україна)

Гурова A.M. кандидат юридичних наук, науковий співробітник відділу проблем аграрного, земельного, екологічного та космічного права Інституту держави і права імені В. М. Корецзького НАН України (м. Київ, Украӥна)

\title{
ЗАРУБІЖНИЙ ДОСВІД ДЕРЖАВНО-ПРИВАТНОГО ПАРТНЕРСТВА ТА МОЖЛИВОСТІ ЙОГО ВПРОВАДЖЕННЯ В КОСМІЧНІЙ ГАЛУЗІ УКРАЇНИ
}

У статті проведено огляд програмних документів космічного та господарського законодавств країн Європи, США, а також права Європейського 
Союзу у сфері державно-приватного партнерства в космічній галузі. Зокрема, проаналізовано такі договірні форми, як концесія, спільна діяльність, трансфер об'єктів інтелектуальної власності тощо, а також інституційні механізми встановлення співпраці публічних і приватних суб'єктів, а саме: Tipping Point (США) та «Спільні технологічні ініціативи», однією з яких є ініціатива у сфері аеронавтики та повітряного транспорту «Clean Sky» (CC). У підсумку виокремлено кілька аспектів, які було б доцільно запозичити для розвитку державно-приватного партнерства у вітчизняній космічній галузі.

Ключові слова: державно-приватне партнерство, спільна діяльність, трансфер технологій, інноваційна платформа.

Постановка проблеми. На світовому ринку космічних послуг i технологій усе більшу роль відіграють приватні суб'єкти, пришвидшуючи 3 кожним роком розвиток космічної галузі. До того ж держави загалом влаштовує статус партнерів у спільних проектах, що обумовлюється розвантаженням державного бюджету та підтриманням вітчизняних приватних ініціатив і зарубіжної інноваційної співпраці. Такі послуги, як постачання вантажів у космос, дистанційне зондування Землі тощо вже десятки років надають приватні компанії в публічних цілях у формі публічно-приватного партнерства в США та Свропі.

Україна тільки зараз торує шлях відкриття державних космічних розробок для комерційного використання. Володіючи конкурентоспроможними технологіями, вона, проте, перебуває в статусі «наздоганяючого суб'єкта ринку космічних послуг», адже за дев'ять років існування законодавчого підгрунтя відносин державно-приватного партнерства (далі - ДПП) лише з розробкою космічної програми на 2018-2022 роки почали говорити про їх використання для розвитку космічної діяльності в Україні. Тож для того, щоб хоч якось синхронізувати вітчизняні інтенції щодо залучення космічної діяльності до відносин з ДПП, а також розвинені правові й організаційні механізми країн 3 тривалою історією ринкових відносин, убачається за доцільне використати компаративний метод.

Аналіз останніх досліджень i публікацій. Вітчизняна наукова література здебільшого зосереджена в царині економічного аспекту досліджуваної проблематики, яку, зокрема, розробляли Ю. В. Бухун, C. В. Войтко, I. В. Дульська та інші. У межах запропонованого дослідження було проаналізовано й іншомовні аналітичні джерела 3 питань правового забезпечення ДПП загалом та його специфіки в космічній сфері зокрема таких авторів, як: Анна Сінуіта, Ден Локней, Девід Айрон, Франсуаз Ваізер та інших. Статтю підготовлено в серії інших досліджень цієї проблематики на виконання Цільової комплексної програми НАН України 3 наукових космічних досліджень на 2018-2022 рр. «Правове забезпечення довгострокової сталості космічної діяльності» (2018-2022), етап 1. «Державно-приватне партнерство у космічній галузі України».

Метою статті є огляд правових механізмів ДПП, які використовуються для розвитку космічної галузі господарювання в США та країнах Свропи, 3 
виявленням аспектів, доцільних для поглибленого вивчення та можливого запозичення у вітчизняній правотворчості й правозастосуванні.

Виклад основного матеріалу. Відповідно до Національної космічної політики США 2010 року в редакції Директиви від 11 грудня 2017 року на НАСА покладено зобов'язання реалізувати інноваційні та сталі програми дослідження 3 комерційними й міжнародними партнерами задля забезпечення експансії людей у Сонячній системі та привнесення на Землю нових знань і можливостей [19]. На підставі цього щорічно розробляють план. Зокрема, на поточний рік визначено, що на НАСА покладається завдання впровадження ефективних партнерських відносин - комерційних, міжнародних, міжвідомчих, академічних та інших, використовуючи ресурси НАСА та розширюючи наукові результати.

Закон США про аеронавтику та космос передбачає два типи угод, які дають змогу встановити партнерські відносини НАСА 3 приватними суб'єктами: 1) угода про спільну діяльність щодо дослідження та розвитку без взаємного фінансування; 2) угода про відшкодування витрат на використання ресурсів НАСА [21].

Відповідно до першої угоди кожна сторона зобов'язується співпрацювати в межах спільного проекту, вкладаючи в нього належні йому технології, устаткування, знання тощо, але фінансуючи при цьому його виконання за власні кошти. Прикладом є так званий договір про спільне дослідження та розвиток (Cooperative Research and Development Agreements (CRADA), що зобов'язує федеральний уряд через свої лабораторії надавати персонал, послуги, об'єкти, обладнання, інтелектуальну власність або інші ресурси без надання фінансових ресурсів приватній стороні для проведення конкретних досліджень у галузі, що узгоджується з діяльністю лабораторій [23, с. 5].

Предметом регулювання другого типу угод може бути діяльність щодо трансферу технологій. Відповідно до Меморандуму Президента США щодо трансферу технологій i комерціалізації федеральних досліджень для сприяння високорозвиненому бізнесу дослідницькі агенції мають використовувати всі можливі правові форми співробітництва задля комерціалізації своїх продуктів, зокрема залучення ДПП у тих технічних сферах, що мають важливе значення для мети діяльності агентств [39]. Після закінчення п'ятирічного строку дії цього акта було прийнято бюджетні пріоритети США на дослідження та розвиток на 2019 рік, відповідно до положень яких агентства мають витрачати кошти так, щоб не дублювати витрат на розробку тих самих технологій у межах країни, а також знижувати державні витрати та збільшувати користь для американського суспільства. Оскільки ранні дослідження характеризуються значним ступенем невизначеності, яка не забезпечує економічного стимулювання, державні дослідницькі агентства мають забезпечити фундаментальні та ранні прикладні дослідження, упровадження яких має забезпечуватися через фінансування більш пізніх етапів з боку фінансового сектору, перетворюючи наукові розробки на комерційні продукти [8].

На виконання вказаних законодавчих положень НАСА пропонує передачу розроблених його персоналом технологій для дальшого 
комерційного впровадження. Юридично така співпраця здебільшого оформляється у вигляді ліцензійних договорів на запатентовані технічні розробки чи програмне забезпечення й отримання за це роялті [5, с. 10]. Проте зауважимо, що укладення ліцензійних угод виходить за межі регулювання Закону США про аеронавтику та космос i має низку специфічних ознак, передбачених законодавством у сфері захисту прав інтелектуальної власності. Зокрема, усі ліцензії НАСА індивідуально узгоджуються з потенційним ліцензіатом й кожна ліцензія містить умови, що стосуються передачі (практичного застосування), тривалості ліцензії, роялті та періодичної звітності. Відповідно до ст.ст. 207-209 розділу 35 Кодексу США федеральне агентство може надавати ексклюзивні або частково ексклюзивні ліцензії на винаходи державної власності задля залучення інвестицій і застосування винаходу. Ліцензія надаватиметься в обсязі, який необхідний для реалізації винаходу та задоволення таким чином публічного інтересу; до того ж не порушуються вимоги антимонопольного законодавства та інтереси держави щодо зовнішньоекономічної торгівлі, а суб'єкт, якому надається ліцензія, здатен реалізувати на практиці винахід у встановлені строки. Крім того, преференція надається малому бізнесу [1], який використовуватиме винахід на території США [49].

Для укладення ліцензійного договору НАСА висуває низку умов як до самого заявника, так і до його діяльності, а саме: 1) детальний план комерціалізації, який має уміщувати огляд того, як компанія планує використовувати ліцензійну технологію, охоплюючи такі положення (але не обмежуючись ними): (а) розробка нового продукту; (b) розширення наявної технології або продукту; (c) упровадження технології для поліпшення наявних процесів; 2) оцінка технології відповідно до ії використання на підставі оцінки поточних потреб ринку; 3) інформація про необхідність залучення додаткових ресурсів НАСА; 4) сфери та регіони, у яких поширюватиметься комерційне використання винаходу, а також передбачувана клієнтська база; 5) персонал, який працюватиме 3 винаходом; 6) джерела додаткового фінансування; 7) найкращі поточні знання заявників, залежно від того, наскільки винахід практикується приватною промисловістю, урядом або і тим, й іншим, а також тим, наскільки винахід комерційно доступний конкуруючим компаніям тощо [12]. Крім того, обов'язково перед укладенням такого роду договорів має проводитись оцінка ринкової вартості винаходу [20 с. 34-37].

Іншою формою ініціювання ДПП у галузі космічної промисловості є Tipping Point соціальних можливостей, за допомогою якого залучаються засоби та кошти представників приватного сектору на розвиток ключових технологій, необхідних як НАСА, так і комерційному сектору загалом [14]. Фінансування в межах Tipping Point передбачає укладення контрактів на фіксовану суму з боку НАСА, вимагаючи внеску з боку приватного суб'єкта не менше 25\% загальної вартості проекту. Крім цього, НАСА передає приватному партнерові об'єкти інтелектуальної власності, засоби тестування, апаратне й програмне забезпечення. 
Процедура Tipping Point полягає в тому, що Управління 3 технологічних аспектів космічних місій HACA (NASA Space Technology Mission Directorate (STMD) на підставі пріоритетів космічної політики та інновацій на ринку космічних технологій країни, що потребують впровадження, оголошує прийняття запитів на інноваційну інформацію, яку відбирає відповідно до таких критеріїв: інвестиції в наземну або космічну інфраструктуру призведуть до значного поліпшення технології і спроможності успішно принести технологію на ринок; уже були зроблені попередні інвестиції для розробки технології (наприклад, за рахунок венчурного капіталу, корпоративних інвестицій тощо); технологія перебуває щонайменше на четвертому рівні готовності на момент подання попередньої пропозиції, тобто має базові функціональні можливості чи критичні програмні компоненти [10]. Указаний орган оцінює відповідні заявки щодо перспективності використання пропонованих технологій для досягнення власних завдань за допомогою проведення низки оцінок. Просування обраних космічних технологій здійснюється до того моменту, коли промисловість без дальших урядових інвестицій зможе розвивати та впроваджувати їх на ринку.

Існують й інші форми угод між НАСА та приватними партнерами, але вони не мають охоплювати державні закупівлі [13, с. 17]. До сфер космічної діяльності, які вже розвиваються в межах ДПП або щодо яких така перспектива окреслена й планується до реалізації найближчим часом, належать обслуговування супутників, конструювання міжпланетних малих супутників, видобування космічних ресурсів за допомогою робототехніки, перевезення вантажів і людей за межі низької навколоземної орбіти, мікрогравітаційні дослідження для застосування в галузі біомедицини, космічна комунікація, дослідження Землі тощо [16, с. 5]. Описані вище форми співпраці між НАСА та приватними суб'єктами господарювання вказують на широке використання різних видів договірних форм для встановлення найоптимальнішої співпраці в межах ДПП відповідно до специфіки проекту, який має бути виконаний для того, щоб задовольнити обидві сторони. До того ж зазначимо, що держава залучається до космічних проектів лише субсидіарно, тобто в разі, коли у приватних суб'єктів виникають труднощі щодо їх самостійного виконання, доводячи в такий спосіб до кінцевого результату розробки обох сторін.

Правове забезпечення відносин ДПП у межах Європейського Союзу (далі - ЄС) дещо складніше, адже передбачає чотири рівні регулювання: наднаціональні норми $Є C$, національне законодавство; норми, що приймаються на локальному рівні; положення контрактів. Як і в США, ЄС розробив низку правил щодо ДПП у сфері інновацій, які постійно еволюціонують. Зокрема, відповідно до Висновку Ради ЄС щодо Європейського дослідницького простору було чітко визначено приватну й публічну ролі, а саме: приватний сектор, який представлений або конкретним підприємством, або їх асоціацією, має визначити рівень технологічних досліджень та інноваційних потреб, а публічний сектор має нести відповідальність за 
рамкові рішення, здійснюючи фінансування на основі широко визнаних кращих практик [4].

Узаємодія цих суб'єктів у межах ЄС у сфері інновацій здійснюється на базі такої інституційної форми співробітництва, як «Спільні технологічні ініціативи», однією з яких є ініціатива в галузі аеронавтики та повітряного транспорту «Clean Sky». Країни-члени ЄC надають фінансову допомогу щодо реалізації цих ініціатив. Кожна ініціатива встановлює власну річну робочу програму, що реалізується спільно, до того ж інші приватні суб'єкти можуть подавати пропозиції щодо дослідницьких проектів та забезпечення розподілу коштів ЄС [11].

Правила реалізащії програми «Горизонт 2020» змінили форму ДПП у СС 3 інституційної на контрактну, закріпивши відповідно до ст. 25 договірні відносини між партнерами, які визначають цілі партнерства, відповідні зобов'язання партнерів, ключові показники ефективності та результати, які необхідно виконати, охоплюючи ідентифікацію досліджень та інновацій, яка потребує підтримки згідно з названою програмою [18]. Приватний сектор виробляє багаторічні дорожні карти ДПП у галузі досліджень, які розглядає Комісія. Указана процедура застосовується для прийняття програми роботи, зокрема обговорення з державами-членами. Після прийняття програми роботи публічні фонди стають доступними для приватних суб'єктів через прозору процедуру конкурентного відбору [17, с. 7]. Отже, ДПП у межах СС передбачає лише процедуру конкурсного відбору приватного партнера та напрями досліджень, які фінансуватимуться за рахунок СС і його держав-членів.

Водночас у пунктах 44-46 Зеленої книги СС щодо ДПП розмежовано предмет правового регулювання у цій сфері: нормативні акти ЄС регулюють процедуру відбору приватного партнера, а національні законодавства формулюють договірні конструкції щодо реалізації ДПП. У пунктах 1, 24, 25 вказаного документа ДПП визначається як форма співпраці між публічною владою та бізнесом, метою якої є сприяння фінансуванню, конструюванню, інноваціям, управлінню чи поліпшенню інфраструктури, які загалом складаються в межах двох моделей: концесійної та приватної фінансової ініціатив [9, с. 9, 14, 15]. Розглянемо їх більш детально на прикладі законодавства космічних держав, зокрема Великобританії й Франції, та його застосування для реалізації проектів ДПП у космічній галузі.

Модель приватних фінансових ініціатив Великобританії передбачає залучення приватних суб' єктів до проектування, будівництва та експлуатації інфраструктури для надання публічної послуги. Ця модель також охоплює розподіл операцій щодо проектування, тестування, будівництва й експлуатації, а також спільне державно-приватне фінансування через інвестиційні платежі чи спільне володіння підприємством-підрядником. До того ж обов'язковою умовою є розподілення ризиків між обома сторонами, адже якщо приватна сторона здійснює фінансування під державні гарантії, то така форма державно-приватної співпраці не вважається приватною фінансовою ініціативою [6; 3]. Володіння активами на завершення контракту зазвичай передається публічному сектору. 
Прикладом успішної реалізації цього виду ДПП у космічній галузі був проект Skynet 5 щодо оновлення супутникової системи, договір про що був укладений між Міністерством оборони Великобританії та дочірньою компанією Airbus corporate (EADS Astrium), відповідно до якого остання відповідала за конструювання й поставку супутників і надання ними послуг. Фінансування проекту одночасно проводилося за рахунок державного бюджету Великобританії, до того ж приватній стороні надавалося право використовувати пропускну здатність сигналу для продажу продукту за межами Великобританії, зокрема НАТО, Канаді, Португалії, Нідерландам, але лише за погодженням Міністерства фінансів Великобританії [6, с. 5]. Вказана компанія й надалі використовує механізми ДПП, зокрема 07 лютого 2018 року між нею та Європейським космічним агентством було укладено договір, відповідно до якого Airbus зобов'язується створити платформу «Бартоломео», яка збільшить здатність модуля «Колумбія» для прийому вантажів, оскільки міститиме 12 слотів для прийому корисного навантаження. Запуск планується вже на травень 2019 року [2].

Наразі у Великобританії відбувається значне реформування інституту ДПП, оскільки національний аудит визначив модель приватних фінансових інвестицій як таку, що не відображає паритету ціни та якості. Це надало активного розвитку іншим формам ДПП, таким як: 1) концесія - приватному суб'єктові надається виняткове право на створення, обслуговування й експлуатацію активів протягом тривалого часу, а робота підрядника оплачується за рахунок доходів від експлуатації об'єкта; 2) стратегічне партнерство у сфері інфраструктури, зміст якого зводиться до спільної діяльності чи створення спільного підприємства, що необхідно для поетапної реалізації проекту; 3) ліцензійний договір на комерційну діяльність, відповідно до якого ліцензіат повертатиме дохід від витрат на розробку та експлуатацію активів; 4) передача в управління приватному суб'єктові державного підприємства; 5) гібридні проекти - об'єднують вищеозначені договори [22].

У Франції існує два типи ДПП: 1) концесійні угоди для реалізації великих інфраструктурних проектів (Закон № 93-122 від 29.01.1993); 2) партнерські контракти (Декрет № 2004-559 від 17.06.2004). Згідно 3 концесійною угодою публічний орган (наприклад, держава чи місцева влада) надає приватній особі право на фінансування, проектування, будівництво, експлуатацію та підтримку проекту, пов'язаного з публічними функціями протягом обмеженого періоду часу. У межах цієї системи всі або частина публічних функцій надаватиметься приватній особі на ії ризик, а ї̈ винагорода виникне значною мірою від комерційної експлуатації послуги. Партнерські договори передбачають, що держава передає приватній стороні на певний період комплексний проект, пов'язаний з проектуванням, будівництвом або поліпшенням, технічним обслуговуванням, експлуатацією чи управлінням роботами, обладнанням або нематеріальними активами, які необхідні для держави, а також повне чи часткове їх фінансування. Головна різниця цих двох типів договорів у тому, що за першим приватна сторона отримуватиме дохід від користувачів публічного сервісу, яким вона управляє, а в другому - безпосередньо від держави. Примітно, що до концесійних угод до введення в дію партнерських контрактів у 
французькій правовій системі використовувалась інша форма контракту: державні закупівлі, які регулюються обмежувальними положеннями Кодексу державних закупівель, який забороняв відстрочені платежі та глобальні тендери для будівництва й експлуатації інфраструктури [7].

Висновки. Огляд зарубіжного правового забезпечення реалізації ДПП у космічній галузі господарювання дає можливість виявити, що цілком резонують самі підходи залучення до ДПП, адже в США та СС використовується платформовий підхід, який передбачає активний діалог між приватним космічним сектором і публічним суб'єктом. Останній накреслює пріоритетні напрями, у які має намір вкладати ресурси, але конкретні проекти формуються вже в результаті співвіднесення їх 3 пропозищіями приватного сектору. В Україні ж діалог поки що лише складається, до того ж космічна діяльність реалізується за державною програмою, до завдань якої приватні суб'єкти можуть лише підлаштовуватись, не займаючи активної, ініціативної позищії.

Крім того, досвід США в досліджуваній сфері яскраво показує перспективність використання такої змішаної договірної форми ДПП, як трансфер технологій, предметом якої є об'єкти інтелектуальної власності, що доводяться до кінцевого користувача приватними суб'єктами. Автори статті в попередніх публікаціях уже вказували на доцільність розвитку в Україні цієї форми ДПП у космічній галузі з накресленням його шляхів. Зарубіжний досвід лише підтверджує раціональність цієї пропозиції, до того ж ще й 3 огляду на наявність перспективних розробок вітчизняних державних підприємств за відсутності достатнього фінансування щодо їх впровадження.

\section{Використані джерела:}

1. Критерії малого бізнесу в США: ст. 632, глави 15 Кодексу США. URL : https:/ / www.gpo.gov/fdsys/pkg/USCODE (дата звернення: 19.02.2019).

2. Bartolomeo: fruit d'un PPP entre Airbus et l'ESA, 07.02.2018. URL : https:/ /operationnels.com/2018/02/07 (дата звернення: 19.02.2019).

3. Compendium of federal public-private partnership authorities for infrastructure investments: CMTS, September 2015 (2005-2015). 13 p. URL : https:/ / www.cmts.gov/Compendium (дата звернення: 19.02.2019).

4. Council conclusions concerning various issues related to the development of the European research area (ERA), 9451/10 rech 173 compet 145, 16 May 2010. URL: http:/ / data.consilium.europa.eu/doc/document (дата звернення: 19.02.2019).

5. Dan Lockney, NASA Technology Transfer Overview. Technology Transfer Program Executive, May 15, 2018. 25 p. URL: https://ipo.lbl.gov/wpcontent/uploads/sites/8/2018/03/NASA-T2-Overview (дата звернення: 19.02.2019).

6. David J. Iron, Ken Davidian Applying the UK's PPP Lessons to NASA's Commercial Development Policy. American Institute of Aeronautics and Astronautics. 8 p. URL: http:/ /commercialspace.pbworks.com.pdf (дата звернення: 19.02.2019).

7. François-Guilhem Vaissier, Hugues Martin-Sisteron and Anna Seniuta, France, The Public-Private Partnership Law Review - Edition 1, published in March 2015 - editors Bruno Werneck and Mário Saadi, 29 p. URL: https://www.whitecase.com (дата звернення: 19.02.2019). 
8. FY 2019 Administration Research and Development Budget Priorities: Memorandum for the heads of executives departments and agencies. August, 17, 2017. URL: https:// www.whitehouse.gov/sites/whitehouse (дата звернення: 19.02.2019).

9. Green paper on public-private partnerships and community law on public contracts and concesssions, 2004, Brussels, 28 p. URL : http://ec.europa.eu/transparency/regdoc (дата звернення: 19.02.2019).

10. Industry-Developed Tipping Point Technologies Request for Information (RFI), responses due: November 28, 2018. URL: https:/ / www.nasa.gov/directorates/spacetech (дата звернення: 05.12.2019).

11. Joint Technology Initiatives, European Parliament, May 2017. URL: http:/ / www.europarl.europa.eu/RegData/etudes/ATAG/2017/EPRS_ATA(2017)60 3936_EN.pdf (дата звернення: 19.02.2019).

12. Licensing Opportunities. Ames Technology Partnerships Office NASA. URL : https:/ / www.nasa.gov/ames-partnerships (дата звернення: 12.02.2019).

13. NASA Partnerships Guide, NASA Advisory Implementing Instruction NAII 1050-3Аб Original Effective Date: December 21, 2016, Last Updated: September 27, 2017, 112 p. URL : https:/ / nodis3.gsfc.nasa.gov/NPD (дата звернення: 19.02.2019).

14. NASA 2018 Strategic Plan, 64 p. URL: https://www.nasa.gov/sites_2018_ strategic_plan.pdf (дата звернення: 11.01.2019).

15. Presidential Memorandum - Accelerating Technology Transfer and Commercialization of Federal Research in Support of High-Growth Businesses: Memorandum for the heads of executive departments and agencies. URL: https:/ / obamawhitehouse.archives. commerciali (дата звернення: 19.02.2019).

16. Public-Private Partnerships for Space Capability Development Driving Economic Growth and NASA's Mission, Interim Report, July 30, 2013, 40 p. URL:https:/ / www.nasa.gov/PotentialMarkets_July2013(дата звернення: 19.02.2019).

17. Public-private partnerships in research European Parliament, May 2017. 12 p. URL: http:/ / www.europarl.europa.eu / RegDBRI(2017) (дата звернення: 19.02.2019).

18. Regulation (EU) no 1291/2013 of the European parliament and of the council of 11 December 2013 establishing Horizon 2020 - the Framework Programme for Research and Innovation (2014-2020) and repealing Decision No 1982/2006/EC. URL: https:/ / eur-lex.europa.eu/legal-content/EN/TXT/PD (дата звернення: 06.12.2019).

19. Reinvigorating America's Human Space Exploration Program, Space Policy Directive 1; SPD 1. URL: https:/ / www.hsdl.org (дата звернення: 19.02.2019).

20. Space Act Agreements Guide (NAII 1050-1D). NASA Advisory Implementing Instruction. Effective Date: February 25, 2013, last updated: 29 September 2017, 217 p. URL: https:/ / nodis3.gsfc.nasa.gov/ (дата звернення: 25.12.2019).

21. Title 51 - national and commercial space programs, enacted by Pub. L. 111314, §3, Dec. 18, 2010, 124 Stat. 3328. URL: http://uscode.house.gov/view.xhtml?path (дата звернення: 11.02.2019).

22. United Kingdom, The Public-Private Partnerships Law Review - Edition 4, Published: April 2018, URL: https://thelawreviews.co.uk/edition/the-public-privatepartnerships-law-review-edition-4 united-kingdom (дата звернення: 25.12.2019).

23. U.S. Code \& 209 - Licensing federally owned inventions. URL: https://www.law.cornell.edu/uscode/text/35/209 (дата звернення: 29.12.2018). 
Малышева Н. Р., доктор юридических наук, профессор, академик НАПрН Украины, заведующая отделом проблем аграрного, земельного, экологического и космического права Института государства и права имени В. М. Корецкого НАН Украины (г. Киев, Украина)

Гурова А. М., кандидат юридических наук, научный сотрудник отдела проблем аграрного, земельного, экологического и космического права Института государства и права имени В. М. Корецкого НАН Украины (г. Киев, Украина)

Зарубежный опыт государственно-частного партнёрства и возможности его внедрения в космической отрасли Украины

В статье осуществлен обзор программных документов космического и хозяйственного законодательств стран Европы и США, а также права Европейского Союза в сфере государственно-частного партнерства в космической сфере. В частности, проанализированы такие договорные формы, как концессия, совместная деятельность, трансфер объектов интеллектуальной собственности и т.д., а также институционные механизмы сотрудничества публичных и частных субъектов, а именно Tipping Point (США) и «Совместные технологические инициативы», одной из которых является инициатива в сфере аэронавтики и воздушного транспорта «Clean Sky» (EC). В результате выделено несколько аспектов, которые было бы целесообразно позаимствовать для развития государственно-частного партнерства в отечественной космической сфере.

Ключевые слова: государственно-частное партнерство, совместная деятельность, трансфер технологий, инновационная платформа.

Malysheva N., Hurova A. Foreign Experience of Public-Private Partnership and the Possibilities of its Implementation into Space Sector of Ukraine

The article was prepared by the authors in a series of other studies on this issue, for the implementation of the National Integrated Program of Space Science Research for 2018-2022 "Legal Provision of Long-Term Sustainability of Space Activities" (20182022), phase 1. "Public-Private Partnership in the space industry". In this article the program acts, space, commercial, budget legislation of USA, of European Union and its Members-States are reviewed. The peculiarities of legal regulation of relationships between public and private subjects in space sphere on the all stages of European legislation were analyzed. Hierarchy of legislation of space activity development in USA was also investigated. Special attention was paid to such contractual forms as concession, strategic partnership, property management, private financial initiatives, common activity, transfer of technologies, mixed contracts etc. and such institutional forms as "Tipping Point" in the USA and "Common Technology Initiatives", especially "Clean Sky" in EU. It is reviewed requirements applied to the private partners in the case of innovative space technologies transfer and procedures is executed in the case of promotion to realize private space start-ups. General overview of space industry that are realized within Public-Private Partnership is considered. Some practical examples of Public-Private Partnership in Great Britain and other countries are reviewed. Differences between "program" and "platform" approaches of the entry to the Public-Private Partnership in space sphere were found out. As the result, it was proposed to change approach of involvement of private partners and build the relationships with them within different forms of PublicPrivate Partnership. It was suggested to develop new form of Public-Private Partnership, which is not reflected in the Law of Ukraine "On Public-Private Partnership", object of which will be intellectual property rights, namely contract of transfer of technologies.

Key words: Public-Private Partnership, common activity, transfer of technologies, innovative platform. 